\title{
Pollution Status of Soils and Vegetation around Busy Motor Parks in Selected Areas of Delta State, Nigeria
}

\author{
Stephen Anapuwa Osakwe \\ Department of Chemistry, Delta State University, Abraka, Delta State, Nigeria.
}

\begin{abstract}
Soil and vegetation samples were collected from busy motor parks in selected parts of Delta State and analysed with the aim of ascertaining the potential and environmental impact of the motor park activities on the surroundings. The physicochemical characteristics of the soil samples were investigated using various standard methods while the heavy metal concentrations were determined using Atomic Absorption Spectrophotometric technique. The pH values ranged from 5.59 to 8.52 with a mean value of 7.21 showing that the soils were slightly acidic to slightly alkaline. The electrical conductivity values ranged from 66.54 to 252.9 $\mu \mathrm{s} / \mathrm{cm}$ with mean value of $163.48 \mu \mathrm{s} / \mathrm{cm}$, indicating presence of high level of soluble inorganic salts in the soil samples. The cation exchange capacity values ( $\left.\mathrm{cmolkg}^{-1}\right)$ ranging from 0.040 to 0.147 with mean value of 0.097 implied that the exchange sites on the soil minerals will be less available for metals retention. The mean percentages of Total Organic Carbon and Total Nitrogen which were 0.488 and 0.107 respectively could be attributed to presence of some biodegradable and compostable materials. The mean concentrations of the heavy metals in the soil samples $\left(\mathrm{mgkg}^{-1}\right)$ were 57.78 for $\mathrm{Fe}, 1.112$ for $\mathrm{Pb}, 0.482$ for $\mathrm{Cu}, 1.334$ for $\mathrm{Zn}$ and 0.13 for $\mathrm{Cr}$ with the abundance trend of $\mathrm{Fe}>\mathrm{Zn}>\mathrm{Pb}>\mathrm{Cu}>\mathrm{Cr}$. The mean metal levels in the vegetation samples ranged from $\left(\mathrm{mgkg}^{-1}\right) 0.152$ to 12.426 with the abundance trend of $\mathrm{Fe}>\mathrm{Pb}>\mathrm{Zn}>\mathrm{Cu}>\mathrm{Cr}$. Soil plant transfer coefficient values for all the metals in all the sites indicate medium accumulation while contamination/pollution index values showed generally very slight contamination. The metal levels in both the soil and vegetation samples in all the sites were relatively higher than the levels recorded in the control sites. The overall results showed evidence of some heavy metals enrichment on the soils and vegetation. This effect could be cumulative over time.
\end{abstract}

Key Words: Heavy metals, physicochemical characteristics, pollution, motor parks, soils, vegetation.

\section{Introduction}

Heavy metals tend to reach the environment from a vast array of anthropogenic sources as well as natural geochemical processes. Some of these anthropogenic sources include wastes from industries, markets, automobile, agricultural and domestic wastes [1].

Automobile emission is perhaps the greatest single source of contamination and it has been shown to contain lead, zinc, cadmium and nickel, the most important being lead from fuels and zinc from tyres [2]. Automobile exhaust account for about $80 \%$ of the air pollution by heavy metals in Nigeria [3]. Several studies have shown that contamination of heavy metals from industries and automobile exhaust can extend to several metres from the point of emission [4,5]. Much attention has been focused towards lead on road side environment as a result of the wide use of this metal in anti-knock additives to petrol [6,7]. Some attention has been focused on the other metals such as cadmium and zinc which derive from tyre abrasion or nickel and chromium which arise from wear of mechanical parts of vehicles [8].

Increased automobile transportation in Nigeria has contributed markedly to the problem of soil contamination in most cities. It has been known that when motor vehicles ply the road, they disperse heavy metals such as lead and zinc, thereby contaminating the roadside soils and constitute health hazards to soil, vegetation and eventually to animals through food chain $[9,10]$.

In addition to normal activities going on in motor parks, there are also occasional servicing and repairs of auto-vehicles and wastes generated such as grease oil, suspended solids, cyanides, alkali, organic solvents contain heavy metals that may be phytotoxic to plants and injurious to animals [11].

The aim of this study was to examine the physicochemical properties of the soil as well as the heavy metals concentrations in both the soil and vegetation in the vicinity of selected busy motor parks in Delta State with a view to establish the pollution or contamination status of the soils and vegetation as a result of activities taking place in the motor parks.

\section{Study Area}

\section{Materials and Methods}

The study area lies roughly between longitude $5^{\circ} 00^{\prime}$ and $6^{\circ} 45^{\prime}$ East and latitude $5^{\circ} 00^{\prime}$ and $6^{\circ} 00^{\prime}$ North. The soil types consist of alluvial soil on the marine deposits along the coast, alluvial and hydromorphic soils on 
marine and lacustrine deposits found in the area closest to the Niger and Benin Rivers, and the feral soil on loose sandy sediments in the dry land area of the North and Northeast. The vegetation ranges from the mangrove swamps along the coast to evergreen forest and savanna in the north. The average temperature of this area is $30^{\circ} \mathrm{C}$ while the average rainfall is $266.5 \mathrm{~cm}$ in the coastal area and $190.5 \mathrm{~cm}$ in the northern part.

The cities selected for the sampling were Abraka, Agbor, Asaba, Sapele and Warri. Abraka, in addition to being a university town, is also a commercial centre with farming, trading and transport services as major occupations. For Agbor, the educational institution (College of Education) coupled with presence of some industries and commercial activities make the parks very busy. Asaba is the capital of Delta State and presence of some industries and commercial centres boost the transport activities. The industries in Sapele such as timber, rubber, palm oil processing as well as furniture and footwear industries lead to a lot of transport activities. Warri, in addition to being a major oil city houses three tertiary institutions and has a lot of industries, markets, transport companies and other commercial establishments.

\section{Sampling}

Soil samples were collected from selected busy and old motor parks in five different towns in Delta State at a depth of $0-15 \mathrm{~cm}$ for top soil, $15-30 \mathrm{~cm}$ for sub-soil and $30-45 \mathrm{~cm}$ for bottom soil. The vegetation around these selected sites were also collected. The sampling locations were

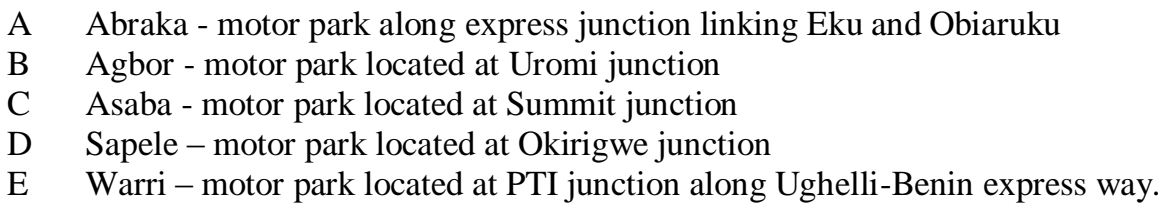

The control samples for both soil and vegetation were collected from location remote from any industrial zone at the outskirts and far removed from the influence of industrial or traffic activity.

\section{Sample Preparation and Analysis}

The soil samples were air-dried for one week in a well ventilated laboratory, crushed in a porcelain mortar, and sieved through a $2 \mathrm{~mm}$ stainless sieve. The $<2 \mathrm{~mm}$ fraction was used for the determination of the selected soil properties.

The vegetation samples were washed with distilled water to remove soil materials and dusts. They were weighed and transferred into the air-circulated oven operating at $40^{\circ} \mathrm{C} \pm 0.5^{\circ} \mathrm{C}$ until they were dried to constant mass. They were then weighed after cooling in a desicator to room temperature $29-32^{\circ} \mathrm{C}$ before they were ground with a milling machine pretreated with nitric acid to avoid contamination by heavy metals and then sieved through $2 \mathrm{~mm}$ sieve.

Soil $\mathrm{pH}$ was measured in a soil water ratio of 1:2.5 [12]. Total Nitrogen (TN) was analysed using micro-kjedahl method [13]. Total organic carbon (TOC), cation exchange capacity ( $\mathrm{CEC}=\mathrm{Na}+\mathrm{K}+\mathrm{Ca}+\mathrm{Mg}$ ) and electrical conductivity were determined using their standard methods respectively $[14,15,16]$.

Total heavy metals were extracted with $4 \mathrm{M}$ nitric acid at $80^{\circ} \mathrm{C}$ for 8 hours [17]. The vegetation samples were digested using $20 \mathrm{~cm}^{3}$ of each acid mixture which consists of nitric acid, perchloric acid and sulphuric acid in the ration 5:1:0.5. The samples were stirred at intervals until complete digestion was achieved. All the digests were cooled and filtered through Whatman No. 42 filter paper and the filterates were analysed for heavy metals using Atomic Absorption Spectrophotometer (Perkin Elmer Model A Analyst 2002) fitted with deuterium lamp for background correction.

All the reagents used in this study were of pure analytical grade and were checked for possible trace metal contamination. All glassware were previously soaked in $14 \%$ nitric acid for 24 hours to remove entrained metals, washed with detergent and rinsed with deionized water.

In the metal analysis by AAS, quality control was monitored using $10 \%$ sample blanks and $10 \%$ sample replicates in each set of sample analysis. The coefficients of variation for replicates were less than $10 \%$ for all the elements. Standard reference material (9SRM 210) was used to check the accuracy of the results. The corresponding results matched within $\pm 1.0 \%$ to $\pm 1.5 \%$.

Soil Physicochemical Characteristics

\section{Results and Discussion}

The physicochemical characteristics of the soil samples are presented on Table 1. 
Table 1: Physicochemical Properties of the Soils from all the Sites

\begin{tabular}{|l|l|l|l|l|l|l|}
\hline $\begin{array}{l}\text { Sample } \\
\text { site }\end{array}$ & $\begin{array}{l}\text { Depth } \\
(\mathrm{cm})\end{array}$ & $\mathrm{pH}$ & $\mathrm{EC} \boldsymbol{\mu \mathrm { s } / \mathrm { cm }}$ & $\% \mathrm{TOC}$ & $\% \mathrm{~N}$ & $\mathrm{CEC}(\mathrm{cmol} / \mathrm{kg})$ \\
\hline $\mathrm{A}$ & $0-15$ & 7.55 & 105.80 & 0.37 & 1.12 & 0.062 \\
& $15-30$ & 6.9 & 211.80 & 0.51 & 0.10 & 0.133 \\
& $30-45$ & 5.59 & 215.50 & 0.43 & 0.09 & 0.128 \\
\hline $\mathrm{B}$ & $0-15$ & 7.49 & 138.10 & 0.12 & 0.10 & 0.085 \\
& $15-30$ & 7.61 & 173.90 & 0.70 & 0.08 & 0.102 \\
& $30-45$ & 6.78 & 152.50 & 0.16 & 0.09 & 0.092 \\
\hline $\mathrm{C}$ & $0-15$ & 6.04 & 75.52 & 0.27 & 0.11 & 0.107 \\
& $15-30$ & 5.85 & 66.54 & 0.51 & 0.13 & 0.112 \\
& $30-45$ & 5.70 & 89.33 & 1.09 & 0.12 & 0.121 \\
\hline $\mathrm{D}$ & $0-15$ & 7.57 & 239.50 & 1.09 & 0.09 & 0.045 \\
& $15-30$ & 7.07 & 252.90 & 0.51 & 0.11 & 0.040 \\
& $30-45$ & 8.52 & 151.30 & 0.47 & 0.10 & 0.052 \\
\hline E & $0-15$ & 8.49 & 184.90 & 0.55 & 0.12 & 0.138 \\
& $15-30$ & 8.42 & 190.90 & 0.31 & 0.11 & 0.147 \\
& $30-45$ & 8.50 & 203.70 & 0.23 & 0.13 & 0.087 \\
\hline Mean & & $\mathbf{7 . 2 1} \pm \mathbf{0 . 0 1 3}$ & $\mathbf{1 6 3 . 4 8} \pm \mathbf{5 8 . 9 3}$ & $\mathbf{0 . 4 8 8} \pm \mathbf{0 . 2 9}$ & $\mathbf{0 . 1 0 7} \pm \mathbf{0 . 2 0 5}$ & $\mathbf{0 . 0 9 7} \pm \mathbf{0 . 1 2}$ \\
\hline Control & $0-15$ & 6.10 & 42.68 & 0.78 & 0.13 & 0.024 \\
& $15-30$ & 6.89 & 79.46 & 0.47 & 0.11 & 0.047 \\
& $30-45$ & 5.58 & 36.74 & 0.47 & 0.10 & 0.022 \\
\hline & Mean & $\mathbf{6 . 1 9}$ & $\mathbf{5 2 . 9 6}$ & $\mathbf{0 . 5 7}$ & $\mathbf{0 . 1 1}$ & $\mathbf{0 . 0 3 1}$ \\
\hline
\end{tabular}

The $\mathrm{pH}$ of the soils in all the sites ranged from 5.59 to 8.52 with a mean value of $7.21 \pm 1.013$ showing that the soils were slightly acidic to slightly alkaline. The values observed in this study are in the same range with the values reported elsewhere [18,19,20], but higher than the values reported in some similar studies $[21,22,23,24]$. The degree of acidity and/or alkalinity is considered a master variable that affects nearly all soil properties (chemical, physical and biological). While some organisms are unaffected by a rather broad range of $\mathrm{pH}$ values, others may exhibit considerable intolerance to even minor variation in $\mathrm{pH}$ [19]. The amount of acid or alkali in soils determines the availability of many nutrients for plants growth and maintenance [25]. Thus, being a key parameter controlling heavy metal transfer behaviour in soils and soil microbial reactions, the observed $\mathrm{pH}$ values in this study may have implications on the availability and uptake of metals by plants and microorganisms.

The electrical conductivity values of the soils in all the sites ranged from $(\mu \mathrm{s} / \mathrm{cm}) 66.54$ to 252.9 with a mean value of $163.48 \pm 58.93$. These values are consistent with the values reported in other related studies $[18,19]$. The values are however higher than those reported in another study [26], but lower than the values reported in some other studies [23,27]. The high conductivity values recorded in this study imply that there is high level of soluble inorganic salts which might have resulted from the presence of some metal scraps and some spilled acids probably from abandoned motor batteries.

The total mean percentages of organic carbon (TOC) and nitrogen (TN) were 0.488 and 0.107 respectively. The values observed for the total organic carbon compared favourably with those reported elsewhere [28], while the values obtained for total nitrogen was consistent with those reported in another related study [29]. These values may be due to presence of some organic matter and some degradable and compostable substances. Organic compounds in soils and sediments play and important role in heavy metal transformation. The complexation reaction between heavy metals and organic complexants is usually recognized as the most important reaction pathway, because this reaction determines to a large extent, the speciation and bioavailability of metal, thereby influencing the mobility of the metal in natural soil or water environment [29].

The cation exchange capacity (CEC) values ranged from $\left(\mathrm{cmolkg}^{-1}\right) 0.040-0.147$ with mean value of $0.097 \pm 0.12$. These values are relatively low compared with those reported in some studies [30,31]. These low cation exchange capacity values imply that the exchange sites on the soil minerals will be less available for metal retention and this leads to the soils lower capacity to adsorb metals. 


\section{Heavy Metals}

Table 2 presents the concentrations of the heavy metals in the soil samples.

Table 2: Concentrations of $\mathrm{Fe}, \mathrm{Pb}, \mathrm{Cu}, \mathrm{Zn}$ and $\mathrm{Cr}$ in the Soil Samples $\left(\mathrm{mgkg}^{-1}\right)$

\begin{tabular}{|l|l|l|l|l|l|l|}
\hline Sample site & $\begin{array}{l}\text { Depth } \\
(\mathrm{cm})\end{array}$ & $\mathrm{Fe}$ & $\mathrm{Pb}$ & $\mathrm{Cu}$ & $\mathrm{Zn}$ & $\mathrm{Cr}$ \\
\hline $\mathrm{A}$ & $0-15$ & 79.488 & 1.156 & 0.470 & 1.198 & 0.145 \\
& $15-30$ & 60.125 & 0.946 & 0.610 & 1.200 & 0.138 \\
& $30-45$ & 28.739 & 0.721 & 0.537 & 1.030 & 0.109 \\
\hline $\mathrm{B}$ & $0-15$ & 82.466 & 1.307 & 0.316 & 1.107 & 0.155 \\
& $15-30$ & 52.392 & 0.845 & 0.274 & 0.925 & 0.143 \\
& $30-45$ & 33.074 & 0.903 & 0.294 & 0.871 & 0.111 \\
\hline $\mathrm{C}$ & $0-15$ & 51.379 & 1.269 & 0.537 & 1.025 & 0.112 \\
& $15-30$ & 23.672 & 1.160 & 0.514 & 1.255 & 0.101 \\
& $30-45$ & 16.751 & 1.071 & 0.534 & 1.120 & 0.098 \\
\hline $\mathrm{D}$ & $0-15$ & 45.338 & 1.638 & 0.431 & 1.107 & 0.132 \\
& $15-30$ & 40.208 & 0.926 & 0.400 & 1.136 & 0.107 \\
& $30-45$ & 32.765 & 0.731 & 0.376 & 1.257 & 0.124 \\
\hline E & $0-15$ & 109.984 & 1.567 & 0.635 & 2.425 & 0.198 \\
& $15-30$ & 107.984 & 1.563 & 0.640 & 2.210 & 0.176 \\
& $30-45$ & 102.466 & 1.477 & 0.664 & 2.142 & 0.155 \\
\hline Mean \pm SD & & $\mathbf{5 7 . 7 8} \pm \mathbf{3 1 . 4}$ & $\mathbf{1 . 1 1} \pm \mathbf{0 . 2 8}$ & $\mathbf{0 . 4 8 2} \pm \mathbf{0 . 1 3}$ & $\mathbf{1 . 3 3 4 \pm 0 . 1 0}$ & $\mathbf{0 . 1 3} \pm \mathbf{0 . 0 3}$ \\
\hline Control & $0-15$ & 6.985 & 0.156 & 0.104 & 0.646 & 0.011 \\
& $15-30$ & 6.213 & 0.112 & 0.056 & 0.790 & 0.005 \\
& $30-45$ & 5.423 & 0.102 & 0.078 & 0.684 & 0.004 \\
\hline Mean \pm SD & & $\mathbf{6 . 2 1} \pm \mathbf{0 . 7 8}$ & $\mathbf{0 . 1 2} \pm \mathbf{0 . 0 3}$ & $\mathbf{0 . 0 7 9} \pm \mathbf{0 . 0 4 6}$ & $\mathbf{0 . 7 0 7} \pm \mathbf{0 . 0 7 5}$ & $\mathbf{0 . 0 1} \pm \mathbf{0 . 0 1}$ \\
\hline
\end{tabular}

The results showed that the heavy metal concentrations were generally higher at the top soils than the sub and bottom soils with few exceptions in some sites. This is expected since the top soils is the point of contact. Previous studies have shown that surface soils are better indicators of metallic burdens [32,33]. The heavy metal levels for all the sites were significantly higher than the levels observed in the control site. This implies that the soils in the vicinity of motor parks have some levels of heavy metal enrichments.

Iron

Iron with the concentrations ranging from $\left(\mathrm{mgkg}^{-1}\right) 16.751$ to 109.984 and mean value of $57.78 \pm 31.40$ had the highest concentrations in all the sites. Similar levels have been reported [34]. These levels are however lower than the levels reported in some other related studies [18,24,35,36] but higher than those reported elsewhere [20,21]. It has been confirmed that natural soils contain significant concentrations of iron [37,38], therefore the relatively high concentrations of iron in the soil samples could be attributed to more of lithorlogical origin than anthropogenic source. However abundance of iron in the motor park soils could also be attributed to presence of some automobile scraps that might have been abandoned at the parks and also from crankshafts wear and engine body damage. High level of iron results in nausea, vomiting, brain haemorrhage, anxiety, tension, cardiac arrest and metabolic disorder [39].

Lead

The lead levels in all the sites ranged from $\left(\mathrm{mgkg}^{-1}\right) 0.721$ to 1.638 with mean value of $1.112 \pm 0.28$. This is consistent with levels reported by some researchers [21,26,39]. These values are however lower than those reported by some other researchers [18,40,41,42]. Generally, lead added to gasoline in tetraethyl form as antiknock agent can be deposited from exhaust pipes in automobiles [35]. Presence of lead could also be attributed to discarded lead-based batteries. Lead poisoning causes gastrointestinal neuromuscular (known as lead leprosy) and central nervous system disorders. It can also cause liver and kidney damage, reduced haemoglobin formation and infertility and birth defects [39].

\section{Copper}

The concentrations of copper ranged from $\left(\mathrm{mgkg}^{-1}\right) 0.274$ to 0.664 with mean value of $0.482 \pm 0.13$. Similar levels have been reported [23]. These levels are however lower than those reported in some other related studies [34,35]. Copper could result from metal bearing wears and babbit metal bushings. It is an essential nutrient and at high concentration, it causes anemia, gastrointestinal disorder and also leads to liver and kidney 
malfunctioning in extreme cases [43]. It has been reported that discarded or disposed used oils that sink into the ground as leachates contain high proportions of $\mathrm{Cu}$, as well as $\mathrm{Pb}$ and $\mathrm{Sb}$ [35].

Zinc

Zinc levels were in the range of $\left(\mathrm{mgkg}^{-1}\right) 0.871$ to 2.425 with mean value of $1.334 \pm 0.10$. These values are consistent with those reported in some studies [21,23,44], but lower than those reported in some other studies [24,26,33]. Presence of zinc could be attributed to corrosion of some metal parts of automobiles. Zinc is also a component of crude oil and automobile (machine) exhaust [2].

Zinc is involved in various physiological and metabolic activities of many organisms but increased level of zinc can cause many health disorders such as diarrhoea, abdominal pain and vomiting [45].

Chromium

Chromium concentrations ranged from $\left(\mathrm{mgkg}^{-1}\right) 0.043$ to 0.194 with mean value of $0.13 \pm 0.03$. These values are in the same range with those reported in some related studies [20,23] but lower than the values reported in some other related studies. Presence of chromium in the soil samples is likely to have resulted from piston rings of automobiles and seals.

Epidemiological studies have shown that chromium compounds have carcinogenic effects $[39,46]$. Chromium is implicated for gastrointestinal hemorrhage, hemolysis, acute renal failure $\left(\mathrm{Cr}^{6+}\right.$ ingestion) [47].

\section{Heavy Metals in Vegetation Samples}

The results of heavy metal concentrations in the vegetation samples are shown on Table 3.

Table 3: Concentrations of $\mathrm{Fe}, \mathrm{Pb}, \mathrm{Cu}, \mathrm{Zn}$ and $\mathrm{Cr}$ in the Vegetation Samples $\left(\mathrm{mgkg}^{-1}\right)$

\begin{tabular}{|l|l|l|l|l|l|}
\hline $\begin{array}{l}\text { Sample } \\
\text { site }\end{array}$ & $\mathrm{Fe}$ & $\mathrm{Pb}$ & $\mathrm{Cu}$ & $\mathrm{Zn}$ & $\mathrm{Cr}$ \\
\hline $\mathrm{A}$ & 15.008 & 0.182 & 0.204 & 0.324 & 0.006 \\
$\mathrm{~B}$ & 7.844 & 0.134 & 0.184 & 0.441 & 0.008 \\
$\mathrm{C}$ & 12.532 & 0.122 & 0.288 & 0.211 & 0.003 \\
$\mathrm{D}$ & 5.990 & 0.154 & 0.297 & 0.657 & 0.012 \\
$\mathrm{E}$ & 20.755 & 0.167 & 0.316 & 0.532 & 0.085 \\
\hline Mean & $\mathbf{1 2 . 4 2 6} \pm \mathbf{5 . 8 8}$ & $\mathbf{0 . 1 5 2} \pm \mathbf{0 . 0 2 4}$ & $\mathbf{0 . 2 5 8} \pm \mathbf{0 . 0 6}$ & $\mathbf{0 . 4 3 4} \pm \mathbf{0 . 1 7}$ & $\mathbf{0 . 0 2 3} \pm \mathbf{0 . 0 4}$ \\
\hline Control & 4.345 & 0.091 & 0.061 & 0.008 & 0.111 \\
\hline
\end{tabular}

All the metals studied were detected in the vegetation samples in all the sites.

Fe with highest levels in the vegetation samples in all the sites ranged from $\left(\mathrm{mgkg}^{-1}\right) 5.990$ to 20.755 with a mean value of $12.426 \pm 5.88$. The iron levels observed in this study are consistent with the levels reported elsewhere [33,48]. Iron is an essential nutrient necessary for chlorophyll synthesis in plants and its deficiency in plants results in distinct yellow or white areas between veins of young leaves leading to spots of dead leaf tissue [49].

Lead levels in the vegetation samples ranged from $\left(\mathrm{mgkg}^{-1}\right) 0.122$ to 0.182 with mean value of $0.152 \pm 0.024$. These values were lower than those reported in another study [50] but higher than the levels reported in some other study [51]. Plant lead content is generally very low due to its low bioavailability [51]. It has been reported that airborne lead from automobile exhaust does not lead to significant contamination of roadside vegetation more than 23 metres from a busy highway [52].

Copper concentrations ranged from $\left(\mathrm{mgkg}^{-1}\right) 0.184$ to 0.316 with mean value of $0.258 \pm 0.06$. Although copper is essential for plant growth, a very small amount of copper is required by plants. The levels obtained in this study are lower than both the typical range in food crops and the level for intolerant plants [53]. Higher level of copper kills or stunts plants growth [50].

Zinc levels in the vegetation samples ranged from $\left(\mathrm{mgkg}^{-1}\right) 0.211$ to 0.657 with mean value of $0.434 \pm 0.174$. These values are lower than those reported elsewhere [50]. The values are lower than both normal and tolerant levels in plants. Zinc is also one of micronutrients essential for normal plant growth but only a small amount of zinc is required $(25-150 \mu \mathrm{g} / \mathrm{g}$ in dry tissue). Zinc in vegetation is less available to animals because studies have shown that zinc accumulates in roots and translocates gradually to leaves [2,51,54].

Chromium concentrations ranged from $\left(\mathrm{mgkg}^{-1}\right) 0.006$ to 0.12 with mean value of $0.023 \pm 0.04$. Similar low level of chromium uptake by vegetation has been reported [55]. Chromium concentrations in normal and tolerant plants are $0.1-0.5 \mathrm{mgkg}^{-1}$ and $10-100 \mathrm{mgkg}^{-1}$ respectively. Most of the chromium in the earth's mantle is insoluble and has low availability to plants [1]. 


\section{Soil Plant Transfer Coefficient or Ratio, of the Heavy Metals}

The uptake of metal ions has been shown to be influenced by the metal species and plant parts [56]. Transfer coefficients (concentration of metal in aerial portion of plant relative to total concentration in the soil) are convenient way of quantifying the relative differences in bioavailability of metals to plants. On the basis of this, the transfer ratio of the metals by vegetation was computed using the method of [57].

The results of the soil plant transfer ratio as computed are presented on Table 4.

Table 4: Soil Plant Transfer Coefficient or Ratio, of the Heavy Metals from all the Sites

\begin{tabular}{|l|l|l|l|l|l|}
\hline & $\mathrm{Fe}$ & $\mathrm{Pb}$ & $\mathrm{Cu}$ & $\mathrm{Zn}$ & $\mathrm{Cr}$ \\
\hline $\mathrm{A}$ & 0.268 & 0.193 & 0.378 & 0.282 & 0.047 \\
$\mathrm{~B}$ & 0.258 & 0.113 & 0.624 & 0.789 & 0.077 \\
$\mathrm{C}$ & 0.224 & 0.126 & 0.545 & 0.106 & 0.022 \\
$\mathrm{D}$ & 0.056 & 0.099 & 0.739 & 0.291 & 0.068 \\
$\mathrm{E}$ & 0.526 & 0.186 & 0.489 & 0.456 & 0.708 \\
\hline
\end{tabular}

The values ranged from 0.022 to 0.789 . These values are consistent with those reported in a similar study [33] and also within the generalized transfer coefficient range for the metals [58]. The values obtained in this study indicate medium accumulation of the metals in the plants (0.01-1.0) [59].

\section{Contamination/Pollution Index (C/P)}

This was computed using Lacatusu, (2000) [60] scheme as follows;

$\mathrm{C} / \mathrm{P}=\underline{\text { Concentration of the metal in soil }}$

Target value

The target value was obtained from the standard formulated by the Department of Petroleum Resources of Nigeria (DPR) cluster abundant values for maximum allowed concentration (ppm) of heavy metals in soils $(\mathrm{Fe}=5000, \mathrm{~Pb}=85, \mathrm{Cu}=36, \mathrm{Zn}=140, \mathrm{Cr}=100)[61]$

The contamination/pollution index values are presented on Table 5.

Table 5: Contamination/Pollution Index of the Metals in all the Sites

\begin{tabular}{|l|l|l|l|l|l|}
\hline & $\mathrm{Fe}$ & $\mathrm{Pb}$ & $\mathrm{Cu}$ & $\mathrm{Zn}$ & $\mathrm{Cr}$ \\
\hline $\mathrm{A}$ & 0.112 & 0.010 & 0.015 & 0.008 & 0.0013 \\
$\mathrm{~B}$ & 0.061 & 0.012 & 0.008 & 0.007 & 0.0041 \\
$\mathrm{C}$ & 0.112 & 0.014 & 0.015 & 0.008 & 0.327 \\
$\mathrm{D}$ & 0.213 & 0.010 & 0.112 & 0.008 & 0.0012 \\
$\mathrm{E}$ & 0.079 & 0.018 & 0.018 & 0.015 & 0.0018 \\
\hline
\end{tabular}

The contamination/pollution index values obtained in this study indicated very slight contamination $(<0.10)$ for all the metals in all the sites except for chromium in site $\mathrm{C}$ which showed moderate contamination $(0.26-0.50)$. Iron however showed slight contamination $(0.10-0.25)$ for sites A, C and D.

\section{Conclusion}

The results of the physicochemical analyses indicate that the soils were slightly acidic to slightly alkaline, electrical conductivity values imply presence of considerable level of soluble inorganic salts. The Total Organic Carbon and Total Nitrogen level confirm presence of some compostable and degradable substances and the values obtained for cation exchange capacity gave an indication that exchange sites on the soil minerals will be less available for metal retention.

The heavy metal levels recorded in this study for all the metals in both soil and vegetation samples are below the common range for agricultural soils, selected average for soils and typical range in food crops as well as DPR target values.

The results for contamination/pollution index and soil plant transfer ratio coupled with the fact that the metal levels in all the sites for both soils and vegetation were higher than the levels recorded in the control samples imply that there is contribution of these metals to the surrounding environment as a result of motor park activities. 


\section{References}

[1]. Alloway, B.J. Heavy metals in soils. Blackie and Son Publishers, Glasgow 2nd Edition. 1990, 158

[2]. Adriano, D.C. Trace elements in terrestrial environment. 2nd Edition. Springer-Verlag Company, New York. 2001.

[3]. Onianwa, P.C. and Fakayoda, S.O. Lead contamination of top soil and vegetation in the vicinity of battery factory in Nigeria. Environ. Geochem. Health 2000, 22: 211-218.

[4]. Welch, W.R. and Dick, D.L. Lead concentration in tissues of roadside mice. Environ. Pollut., 1975, 8(1): 151-157.

[5]. Nriagu, J.O. The biogeochemistry of lead in environment. Part A. Elsevier/North Holland Inc. Amsterdam, 1978, 10-15.

[6]. David, D.J. and Williams, C.H. Heavy metal content of soils and plants adjacent to the Hume Highway near Marulan, New South Wales. Exp. Agric. Anim. Husb. 1975, 15: 414-415.

[7]. Mankovska, B. The content of lead, cadmium and chlorine in forest trees caused by traffic of motor vehicles. Biol. Bratisl., 1977, 32: 477-489.

[8]. Fergusson, J.E., Hayes, R.W., Yong, T.G and Thiew, S.H. Heavy metal pollution by traffic in Christ church New Zealand, lead and cadmium content of dust, soil and plant samples. New Zealand J. Sci., 1980, 23: 293-310.

[9]. Ndiokwere, C.L. A study of metal pollution from motor vehicles emissions and its effects on roadside soils, vegetation and crops in Nigeria. Environ. Pollut. Series B, 1984, 35-42.

[10]. Egboh, S.H.O., Nwajei, G.E. and Adaikpoh, E.O. Selected metal concentrations in sediments from major roadside gutters in Warri, Delta State, Nigeria. Nig. J. Sci. Environ., 2000, 2: 105-111.

[11]. FEPA. Guideline and Standards for Environmental Protection Agency, Lagos, Nigeria. 1991.

[12]. Davey, B.J. and Conyers, M.K. Determining the pH of acid soils. Soil Sci., 1988, 146: 141-150.

[13]. Bremner, J.M. Total nitrogen. In: Black, C.A. (Ed) Methods of soil analysis. Part 2. Agronomy, 1965, 9: 1149-1178.

[14]. Nelson, D.W. and Sommers, L.E. Total organic carbon and organic matter. In: Methods of soil analysis. In Page A.Z. (ed) 1982, 539571 .

[15]. Jackson, M.L. Soil chemical analysis. Prentice Hall, New York. 1960.

[16]. Chopra, G. and Kanzar, C. Analytical agricultural chemistry. 2nd Edition. Prentice-Hall, India. 1988.

[17]. Bradford, G.R., Page, A.L., Lund, L.J. and Olmstead, W. Trace elements concentrations of sewage treatment plant effluents and sludge. The interactions with soil and uptake by plants. J. Environ. Qual., 1975, 4: 123-127.

[18]. Akpoveta, O.V., Osakwe, S.A., Okoh, B.E. and Otuya, B.O. Physicochemical characteristic and levels of some heavy metals in soils around metal scrap dumps in some parts of Delta State, Nigeria. J. Appl. Sci. Environ. Manag., 2010, 14(4): 57-80.

[19]. Obasi, N.A., Akubugwo, E.I., Ugbogu, O.C. and Otuchristian, G. Assessment of physicochemical properties and heavy metals bioavailability in dumpsites along Enugu-Port Harcourt expressways, South-east, Nigeria. Asian J. Appl. Sci., 2012, 5: $342-356$.

[20]. Okorie, E.O. and Egila, J.N. Distribution of metals in an abandoned coal mine over burden soil from Okaba, Kogi State, Nigeria. J. Chem. Soc. Nig., 2012, 37(2) 41-53.

[21]. Oviasogie, P.O. and Ofomaja, A. Available $\mathrm{Mn}, \mathrm{Zn}, \mathrm{Fe}, \mathrm{Pb}$ and physicochemical changes associated with soil receiving cassava mill effluent. J. Chem. Soc. Nig., 2007, 31(1), 69-73.

[22]. Rashad, M. and Shalaby, F.A. Dispersion and deposition of heavy metals around Municipal Solid Waste (MSW) dumpsites, Alexandria, Egypt. American-Eurasian J. Agric. Environ. Sci., 2007, 2(3): 204-212.

[23]. Osakwe, S.A. and Akpoveta, O.V. Effect of cassava processing mill effluent on physical and chemical properties of soils in Abraka and environs, Delta State, Nigeria. Pac. J. Sci. Technol., 2012, 544-554.

[24]. Osakwe, S.A. Effect of cassava mill effluent on physical and chemical properties of soils in Abraka and environs, Delta State, Nigeria. Chem. Mat. Res., 2012, 2(7): 27-39.

[25]. Gauch, H.G. Inorganic plants nutrition. Dowder Hutchinson and Ross Inc. Stroudsburg, Penyslvania, 1972 , p. 448.

[26]. Oviasogie, P.O. and Omoruyi, E. Levels of heavy metals and physicochemical properties of soil in a foam manufacturing industry. $J$. Chem. Soc. Nig., 2007, 32(1): 102-106.

[27]. Isirimah, N.O. An inventory of some chemical properties of selected soils of Rivers State of Nigeria. In Proceeding of $15^{\text {th }}$ Annual Conference of Soil Science Association of Nigeria, Kaduna, 1987, 217-233.

[28]. Osenwata, O.I. Effects of abatour effluent on the physical and chemical properties of soils. Environ. Monit. Assess., 2009,1058-1068.

[29]. Peng, J., Song, Y.,Yuan, P., Cui, X. and Qiu, G. The remediation of heavy metals contaminated sediment. J. Haz.. Mat., 2009, 161: 633-640.

[30]. Odu, C.T., Esuruoso, O.F., Nwobosho, I.C. and Ogunwala, J.A. Environmental study (soil and vegetation) of Nigeria's Agip oil Company Operation Area. A report submitted to Nigeria Agip Oil Company Ltd., Lagos. 1991.

[31]. Iwegbue, C.M.A., Isirimah, N.O., Igwe, C. and William, E.S. Characteristic levels of heavy metals in soil profile of automobile mechanic waste dumps in Nigeria. Environmentalist, 2006, 26: 131-137.

[32]. Nyangababo, J.T. and Hamuya, J.W. The depositions of lead, cadmium, zinc and copper from motor traffic on Brachiaria enum and soil along a major Bombay road in Kampala city. Inter. J. Environ. Stud., 1986, 28: 115-119.

[33]. Amusan, A.A, Ige, D.V. and Olawale, R. Characteristics of soils and crop uptake of metals in municipal waste dumpsites in Nigeria. J. Hum. Ecol., 2005, 17(3) 167-171.

[34]. Urunmatsoma, S.O. and Ikhuoria, E.U. Effect of leachates (heavy metal content) from solid waste at "Effurun roundabout dumpsite", Warri, Nigeria. Chem. Tech. J., 2005, 1: 195-202.

[35]. Oguntimehin, I. and Ipinmoroti, K. Profile of heavy metals from automobile workshops in Akure, Nigeria. J. Environ. Sci. Technol., 2007, 1-8.

[36]. Osakwe, S.A. Assessment of the effects of wood processing industries in selected parts of Delta State, Nigeria, on the soils and vegetation in their vicinities. IOSR J. Appl. Chem., 2013, 3(3): 22-30.

[37]. Ademoroti, C.M.A Environmental Chemistry and Toxicology. Foludex Press Ltd., Ibadan, 1996, 150-188.

[38]. Aluko, O.O. and Oluwande, P.A. Characterization of leachates from a municipal solid waste landfill site in Ibadan, Nigeria. Journal of Environ. Health Res., 2003, 2: 83-84.

[39]. Kaur, S. and Mehra, P. Assessment of heavy metals in summer and winter seasons in River Yamuna segment flowing through Delhi, India. J. Environ. Ecol., 2012, 3(1) 1-17.

[40]. Okuo, J.M. and Iyasele, J.U. A study of heavy metals composition of total suspended particulate matter around industrial complexes in Edo State, Nigeria. J. Chem. Soc. Nig., 2007, 32(1): 32-37.

[41]. Abeh, T., Gungshik, J. and Adamu, M.M. Speciation studies of trace elements levels in sediments form Zaramagada stream in Jos, Plateau State, Nigeria. J. Chem. Soc. Nig., 2007, 32(2): 218-225.

[42]. Njoku, P.C. and Ayoka, K.O. Evaluation of heavy metal pollution from soils at Municipal Solid Waste (MSW) deposit in Owerri, Imo State, Nigeria. J. Chem. Soc. Nig., 2007, 32(1): 57-60.

[43]. USEPA. National primary drinking water regulation. United States Environmental Protection Agency. 1999. 
[44]. Adaikpo, E.O., Kaizer, A.N. and Osakwe, S.A. Distribution of heavy metals in subsurface soils in Abraka and environs, southwestern Nigeria. Afr. Scientist, 2005, 6(1) 29-33.

[45]. Pillai, K.C. Heavy metals in aquatic environment. Water pollution and management (Varshey C.K) New Delhi. Wiley, 1983, 74-93.

[46]. Moore, J.W. and Ramamoorthy, S. Heavy metals in natural waters. Applied Monitoring and Impact Assessment New York, Springer, $1984,1-268$.

[47]. Soghvian, S. Heavy metal toxicity medscape reference, drugs, diseases and procedures. Updated May 6, 2011, 1-7.

[48]. Asomugha, R., Orisakwe, O.E., Afonne, O.J., Obi, E., Nduka, J.C. and Dioka, C.E. Impact of effluents from cable manufacturing plant on food, water and soil qualities on Nnewi, Nigeria. Pakistan J. Biol.. Sci., 2005, 8(5) 744-747.

[49]. Bennett, W.F. Nutrient Deficiencies and Toxicities in Crop Plants. APS Press, St. Paul, Minnesota, 1993.

[50]. Okoronkwo, N.E., Igwe, J.C. and Onuchukwu, E.C. Risk and health implications of polluted soils for crop production. Afr. J. Biotechnol., 2005, 4(13): 1521-1524.

[51]. Jung, M.E. Heavy metal concentrations in soils and factors affecting metal uptake by plants in the vicinity of a Korean Cu-W mine. Sensors, 2008, 8: 2413-2423.

[52]. National Academy of Sciences. Airborne lead in perspecti8ve Washington D.C. 1972.

[53]. Walsh, C.J. Urban impacts on the ecology of receiving water. A frame work for assessment, conservation and restoration. Hydrobiologia, 2000, 341: 107-114.

[54]. Chiroma, T.M., Hymore, P.K. and Ebawele, R.O. Heavy metal concentrations in vegetations and soils irrigated with sewage water in Yola. NJERD, 2003, Vol. 2, No. 3.

[55]. Osabohien, E. and Otuya, O.B. Heavy metals in soils, tubers and leaves of cassava (Manihot esculenta) plants grown around some oil spill and gas flaring zones in Delta State, Nigeria. Europ. J. Sci. Res., 2006, 13(1): 53-57.

[56]. Juste, C. and Mench, M. Long term application of sewage sludge and its effects on metal uptake by crops. In: Biogeochemistry of Trace Metals. Adriano D.C. (ed) CRC Press Boca Raton, 1992, 159-194.

[57]. Oyedele, D.I., Obioh, I.B., Adejumo, J.A., Oluwole, A.E., Aina, P.O. and Asubiojo, O.I. Lead contamination of soils and vegetation in the vicinity of a lead smelter in Nigeria. The Sci. Total Environ.,1995, 172: 189-195.

[58]. Kloke, A., Saurebeck, D.R. and Vetter, E.U. Effect of leachates (heavy metal content) from solid waste at "Effurun roundabout dumpsite", Warri, Nigeria. Chem. Tech. J., 2005, 1: 195-202.

[59]. Kabata-Pendias, A. and Pendias, H. Trace elements in soils and plants (2nd edition) CRC Press, Boca Raton, FL. 1992.

[60]. Lacatusu, R. Appraising levels of soil contamination and pollution with heavy metals. Europ. Soil Bureau Res. Report, 2000 , No. 4. 393-402.

[61]. DPR. Environmental Guidelines and Standards for the petroleum Industry in Nigeria (Revised Edition). Department of Petroleum Resources, Ministry of Petroleum and Mineral Resources. 2002. 